\title{
Analysis of mode transportation performance and satisfaction level of Jenggala Commuter Line (Sidoarjo-Mojokerto)
}

\author{
Hera Widyastuti ${ }^{1, *}$, Asep Yayat Nurhidayat ${ }^{2}$, Ahmad Soimun $^{2}$, Cahyani Setyarini ${ }^{2}$, \\ Nafilah El Hafizh ${ }^{2}$, and Arinda Leliana ${ }^{2}$ \\ ${ }^{1}$ Civil Engineering, Faculty of Civil Environmental and Geo Engineering, 6011 Surabaya, Indonesia \\ ${ }^{2}$ Civil Engineering, Faculty of Civil Environmental and Geo Engineering, 6011 Surabaya, Indonesia
}

\begin{abstract}
The increasing traffic density in Sidoarjo-Mojokerto is caused by the inadequancy of road capacity available to handle the growth of vehicle every years, and as a result, traffic jams arise in the highway, travel time will be extended, and require more cost. Therefore to handle this situation a mode of transportation which can carry a mass of passengger in the same time or a mass rapid transit, is necessary. Every customer demand the best service they can get from the transport provider and as a result that make an important indicator to measure the quality of performance or service. Analysis results reveal that travel in 45 minutes, boardingalighting ranges from 1-3 minutes, Load factor 0.88. Based on the results of the analysis of the customer satisfaction level of conformity obtained on Jenggala commuter line IPA analysis with an average of $93.5 \%$ which shows that the customer are satisfied with the service and with a CSI value of 0.827 .
\end{abstract}

\section{Introduction}

Jenggala commuter line is one of the train line operated by PT Kereta Api Indonesia which serves 6 times route between Sidoarjo-Mojokerto (passengers service). The route between Sidoarjo and Mojokerto is estimated to take 45 minute from departure to arrival. This train will serve the line from Sidoarjo Station, Tulangan Station, Tarik Station, and to end its journey at Mojokerto Station. Increased traffic density in Sidoarjo and Mojokerto arise because the existing road capacity is not proportional to the increase in traffic volume which caused by the increasing number of private vehicle users such as cars and motorcycles. To overcome these problems, it is necessary to provide a mode of transportation that can move a massive number of passenger at the same time, or often referred to as mass rapid transport. The mass rapid transport available between SidoarjoMojokerto is Jenggala commuter line or commonly called KA Komuter SIMO.

The existence of Jenggala commuter line is in an effort to improve its performance requires assessment of perceptions and expectations of service users. Because service users

* Corresponding author: hera.widyastuti@yahoo.co.uk 
are the most eligible parties to evaluate and measure the extent to which service quality they receive.

One of the indicator for assesing performance is to assess the minimum service standards provided by the railway service providers both in terms of in terms of infrastructure (stations) and the means (railway). The Government has issued several regulations on service standards at the station that is Minister of Transportation Regulation No.48 of 2015 on Minimum Service Standards For Railway Trainers and Station Standardization Guidelines of 2012 [1]. Based on this rule it is necessary to evaluate the extent to which the application of minimum service standards And transportation infrastructure Jenggala commuter line.

\section{Methodology}

This research was conducted by using interview system to the respondents to obtain their satisfaction of Jenggala comuuter line and direct survey in field to know the performance of Jenggala commuter line. To measure respondent satisfaction of various factors relating to the operation of commuter trains used a questionnaire with the question format adapted to the Importance Performance Analysis (IPA). Data collection was done by distributing questionnaires to 51 respondents on weekdays. Preliminary survey conducted to evaluate the questionnaire and to test the validity and reliability to test whether each question is valid and reliable. In addition to interviews and questionnaires, this study also conducted a survey directly in the field to obtain primary data including the time of departure and arrival between trains (headway), the travel time between stations (travel time), comfort seating and standing capacity of carriages, the total capacity of the train fire and load factor.

The importance of the quality of service is how important a variable of service for customers to service performance [2]. The 5-level Likert scale is used to measure the level of importance that is very important, important, quite important, less important and not important. These five levels are scored as follows Very important answer given a score of 5, Important answer is given a score of 4, Quite important answer is given a score of 3, Less important answers are given a score of 2, An unimportant answer was given a score of 1.

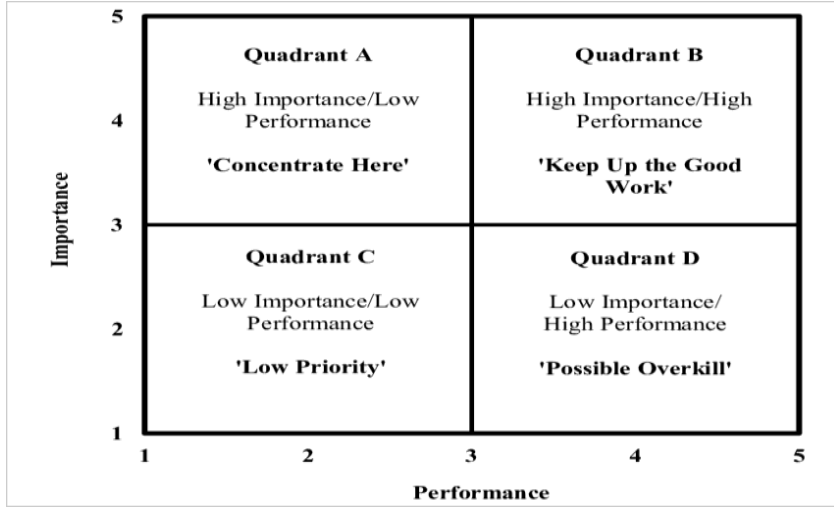

Fig. 1. Importance-Performance Grid Cartesian Diagram

\section{Analysis and Discussion}

Equations should be centred and should be numbered with the number on the right-hand side. 


\subsection{Facilities of Jenggala Commuter Line}

The Jenggala commuter line owned by the Indonesian Ministry of Transportation and operated by PT Kereta Api Indonesia in Java serving the Mojokerto-Tulangan-Sidoarjo route. The train was inaugurated on November 12, 2014 to serve pioneer routes on the line between Sidoarjo Station to Tulangan Station, Tarik Station and continued to Mojokerto Station. Jenggala commuter line facility consists of two series of the latest air conditioning KRDI made by PT Industri Kereta Api (INKA) Madiun, each consisting of four units of diesel economy class railway rail.

\subsection{Jenggala Commuter Line Performances}

\subsubsection{Train boarding-alighting}

Data that can also be obtained from this survey is a train waiting time from the difference between actual departure time and actual arrival time. Furthermore this study can show the value of time delay from the difference between actual departure and arrival time with scheduled departure and arrival.

Table 1. Boarding-alighting on Sidoarjo Station-Mojokerto Station Line (PM).

\begin{tabular}{|l|c|c|c|c|c|c|c|c|}
\hline \multirow{2}{*}{ Station } & \multicolumn{2}{|c|}{ KA 289 } & \multicolumn{2}{c|}{ KA 295 } & \multicolumn{2}{c|}{ KA 294 } & \multicolumn{2}{c|}{ KA 296 } \\
\cline { 2 - 9 } & Schedule & Survey & Schedule & Survey & Schedule & Survey & Schedule & Survey \\
\hline Sidoarjo & 2.35 & 2.34 & 4.45 & 4.44 & 4.45 & 4.45 & 3.05 & 3.03 \\
\hline Tulangan & 2.35 & 2.31 & 4.45 & 4.45 & 4.45 & 4.45 & 3.05 & 3.05 \\
\hline Tarik & 2.49 & 2.49 & 4.45 & 4.45 & 4.45 & 4.45 & 3.05 & 3.05 \\
\hline Mojokerto & 2.49 & 2.48 & 4.45 & 4.41 & 4.45 & 4.41 & 3.05 & 3.04 \\
\hline
\end{tabular}

\subsubsection{Travel time}

As a survey conducted on May 17, 2017 and May 19, 2017 in conjunction with the survey of the number of passengers up and down are also carried out during peak hours (peak hours).

Table 2. Travel Time Route Station Sidoarjo-Station Mojokerto.

\begin{tabular}{|l|c|c|c|c|}
\hline \multirow{2}{*}{ Station } & \multicolumn{2}{|c|}{ Survey } & \multicolumn{2}{c|}{ Travel Time } \\
\cline { 2 - 5 } & Departure & Arrived & Schedule & Survey \\
\hline Sidoarjo & 4.04 & 4.06 & & \\
\hline Tulangan & 4.17 & 4.18 & 00.13 & 00.12 \\
\hline Tarik & 4.38 & 4.40 & 00.21 & 00.22 \\
\hline Mojokerto & 4.45 & 4.51 & 00.11 & 00.11 \\
\hline
\end{tabular}

Travel Time $=45$ minutes $=2,700$ second. According to the field survey and according to PT KAI schedule, the average travel time for the Jenggala Sidoarjo-Mojokerto railway in the afternoon is 45 minutes.

\subsubsection{Car carriage capacity}


The capacity of the carriage can be known from the measurement of the seating dimension and the place to stand on the train. Jenggala train uses inter-city economic railway train which has seat type 2 seating. The distance between the side facing seat and the floor of the vehicle used for the standing passenger. The area provided for the standing area is the floor of the vehicle squeezed by the two adjacent seats as well as the area that is on the train bordes as the train is running.

\subsubsection{Seating comfortability}

$\mathrm{R}=\mathrm{Ad} / \mathrm{m}$

$=((0.9 \times 0.5) \times 18)+(0,9 \times 0,5) \times 18)) / 72$

$\mathrm{R}=0.255 \mathrm{~m} 2 /$ space.

Then the comfortability of Jenggala commuter line seating would not meet the comfort standard of $0,3-0,5 \mathrm{~m}^{2} /$ space.

\subsubsection{Standing place comfortability}

Empirically the standing place in Jenggala commuter line have meet its standart with standing space more than $0.25 \mathrm{~m} 2 /$ space. And there are handles provided.

$\mathrm{M}^{\prime}=\mathrm{Ab} / \mathrm{Alfa}$

$=(16 \times 0.55)+(1.4 \times 2.76)+(1.4 \times 2,76) / 0,25=(8.8+3.9+3.9) / 0.25=66$ passengers

\subsubsection{Train totalcCapacity}

Train capacity according to real conditions can accomodate sitting and standing passengers with a capacity of $20 \%$ from the total seating capacity. The capacity of one car as mentioned earlier is 72 for sitting and 22 for standing passengers, in this way the total capacity ( $\mathrm{Cv} 1)$ for each train consisting of 4 car each are:

$\mathrm{Cv} 1=\left(\mathrm{m}+\mathrm{m}^{\prime}\right) \times$ number of cars $=(72+66) \times 4=552$ passengers

Capacity in accordance with the statement of the Director of PT KAI that the capacity of the rail transport economy is $100 \%$ of seated passengers. So the total capacity (Cv2) for 1 (one) series of Jenggala commuter line consisting of 4 units of carriages are:

$\mathrm{Cv} 2=\mathrm{m} \times$ number of cars $=72 \times 4=288$ passengers

\subsubsection{Load factor}

Load factor analysis on Jenggala commuter line is the calculation of the terms of each station. The stages in calculating the load factor on each station is follows:

- Conducting on train survey to obtain the number of passenger boarding and leaving the train at each station.

- Calculate the summary of passenger in the following way: The number of passenger on the first station is the summary of passenger boarding and the amount of passenger of the next station.

- The Load factor in accordance with the statement of Director of PT KAI that economic train transport capacity is $100 \%$ of passengers seated. Number of seats per carriage is 72 seats, and a series of trains consisting of four (4) carriage. So that the capacity of the train is 288 seats

$\mathrm{LF}=\frac{((\text { Boarded Pass }+ \text { Boarding Pass })-\text { Leaving pass }}{\text { capacity }}$
$\mathrm{LF}=\frac{((0+254)-0}{288}=0.88$ 
And for Load factor in full condition and passenger all standing:

$\mathrm{LF}=\frac{((0+254)-0}{532}=0.48$

Table 3. Load Factor Jenggala Commuter Line Sidoarjo Station-Mojokerto Station.

\begin{tabular}{|l|c|c|c|c|}
\hline \multirow{2}{*}{ Station } & \multicolumn{3}{|c|}{ Passanger } & \multirow{2}{*}{ Load Factor } \\
\cline { 2 - 4 } & Boarding & Alighting & Total & \\
\hline Sidoarjo & 254 & 0 & 254 & 0.88 \\
\hline Tulangan & 13 & 0 & 267 & 0.93 \\
\hline Tarik & 0 & 13 & 254 & 0.88 \\
\hline Mojokerto & 0 & 254 & 0 & 0.00 \\
\hline
\end{tabular}

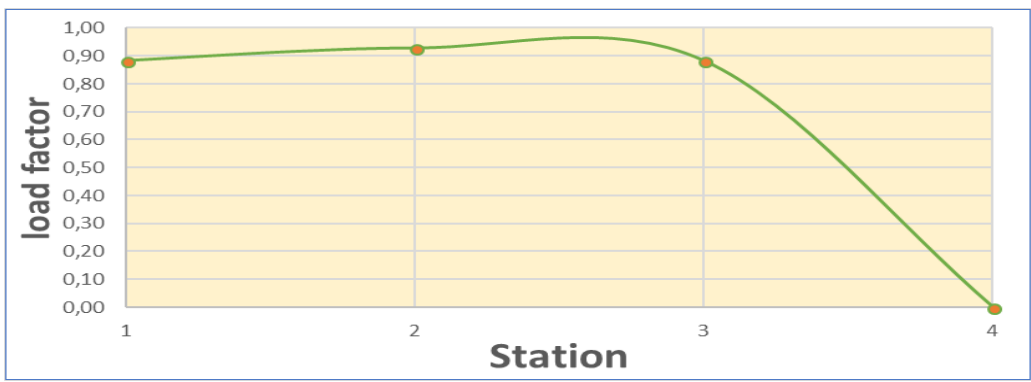

Fig. 2. Load Factor Jenggala Commuter Line Sidoarjo Station-Mojokerto Station

Table 4. Variable and Percentage Commuter Line Sidoarjo Station-Mojokerto Station.

\begin{tabular}{|c|c|}
\hline Variable & Percentage \\
\hline Gender & Male : $39.22 \%$, Female : $60.78 \%$ \\
\hline Age & $\begin{array}{l}\text { At the age of } 18-25 \text { are } 39,22 \%, \\
\text { At the age of } 36-45 \text { are } 25,49 \%, \\
\text { At the age of } 26-35 \text { are } 23,53 \% \\
\text { And at the age of } 46-55 \text { are } 11,76 \%\end{array}$ \\
\hline Occupation & $\begin{array}{l}\text { Student } 15,69 \% \text {, } \\
\text { Housewive } 19,61 \% \text {, } \\
\text { Employee } 35,29 \% \text {, } \\
\text { Businessman } 15,69 \% \\
\text { And Teacher } 3,92 \% \text {. } \\
\end{array}$ \\
\hline Income rate & $\begin{array}{l}\text { Rp.2.500.000-Rp.5.000.000,- = 39,22\%. } \\
\text { >Rp.5.000.000 =5,88\%. Rp.1.500.000,- } \\
\text { Rp.2.500.000,- }=19,61 \% \text {, Rp.500.000,-Rp. } 1.500 .000,- \\
=13,73 \%, \text { Rp. } .500 .000=21.57 \%\end{array}$ \\
\hline Travel Destination & $\begin{array}{l}\text { Private bussiness } 13,73 \% \text {, Shopping and recreation } \\
13,73 \% \text {, work } 39,22 \% \text { and study } 17,65 \% \text {. }\end{array}$ \\
\hline $\begin{array}{l}\text { Transportation mode used before } \\
\text { Jenggala commuter line }\end{array}$ & $\begin{array}{l}\text { Motorcycle }=49.02 \% \text {, Private car }=27.45 \% \text {, Public } \\
\text { Transport }=13.73 \% \text {. }\end{array}$ \\
\hline $\begin{array}{l}\text { Reasons to switch to using } \\
\text { Jenggala commuter line }\end{array}$ & $\begin{array}{l}\text { Faster travel }=47.07 \% \text {, Cheaper cost }=21.57 \% \text {, Safe and } \\
\text { Comfortable }=23.53 \% \text {, Distance from station to } \\
\text { destination }=7.84 \%\end{array}$ \\
\hline Mode used to reach station & $\begin{array}{l}\text { Motorcycle }=70.59 \% \text {, Private car }=11.76 \% \text {, Public } \\
\text { Transport }=7.84 \% \text {, walking }=5.88 \% \text { and other }=3.92 \%\end{array}$ \\
\hline $\begin{array}{l}\text { Mode used to reach destination } \\
\text { from station }\end{array}$ & $\begin{array}{l}\text { Motorcycle }=47.06 \% \text {, Private car, Public Transport }= \\
17.65 \% \text {, walking, others }=7.84 \% \text { dan pedicab (rickshaw) } \\
=1.96 \%\end{array}$ \\
\hline
\end{tabular}


Table 5. Validity and Reliability Test of Jenggala Commuter Line Performance.

\begin{tabular}{|l|c|c|c|c|}
\hline \multirow{2}{*}{ Station } & \multicolumn{3}{|c|}{ Passanger } & \multirow{2}{*}{ Load Factor } \\
\cline { 2 - 4 } & Board & Leave & Total & \\
\hline Mojokerto & 94 & 0 & 94 & 0.33 \\
\hline Tarik & 9 & 1 & 102 & 0.35 \\
\hline Tulangan & 4 & 14 & 92 & 0.32 \\
\hline Sidoarjo & 0 & 92 & 0 & 0.00 \\
\hline
\end{tabular}

\subsubsection{Validity and reliability test}

The validity test is used to determine the feasibility of the questionnaire question items in defining a variable. Questionnaire question items should in principle support certain variables that are used as research variables. The criteria used to judge the validity of the test results is the value of the correlation ( $\mathrm{r}$ ), which is called the coefficient of validity. $\mathrm{R}$ value calculation results compared with the value of $r$ tables where if the value of $r$ table is smaller than the value of $r$ count then the questions are considered valid.[3]

The Reliability Test is a measure of stability and consistency of respondents in answering questions items related to the dimensions of research variables. Reliability provides an illustration of the extent to which a measurement result can be reliable that means the extent to which the score of measurement results free from measurement error.

Table 6. Load Factor Jenggala Commuter Line Sidoarjo Station-Mojokerto Station.

\begin{tabular}{|c|c|c|c|c|c|c|c|c|}
\hline \multirow{2}{*}{ Att. } & \multicolumn{2}{|c|}{ R Valuae } & \multirow{2}{*}{$\underset{\text { table }}{r}$} & \multirow{2}{*}{ Remark } & \multicolumn{2}{|c|}{ R Valuae } & \multirow{2}{*}{$\underset{\text { table }}{\mathbf{r}}$} & \multirow{2}{*}{ Remark } \\
\hline & Satisfaction & Expectation & & & Satisfaction & Expectation & & \\
\hline $\mathrm{P} 1$ & 0,4174 & 0,4867 & 0,2759 & Valid & 0,6790 & 0,2868 & 0,2759 & Reliabel \\
\hline P2 & 0,3776 & 0,7648 & 0,2759 & Valid & 0,4829 & 0,3560 & 0,2759 & Reliabel \\
\hline P3 & 0,4970 & 0,6032 & 0,2759 & Valid & 0,2845 & 0,5106 & 0,2759 & Reliabel \\
\hline P4 & 0,4838 & 0,5073 & 0,2759 & Valid & 0,4083 & 0,3260 & 0,2759 & Reliabel \\
\hline P5 & 0,4558 & 0,6953 & 0,2759 & Valid & 0,5329 & 0,6990 & 0,2759 & Reliabel \\
\hline P6 & 0,2788 & 0,6866 & 0,2759 & Valid & 0,3122 & 0,4898 & 0,2759 & Reliabel \\
\hline P7 & 0,5116 & 0,5620 & 0,2759 & Valid & 0,5244 & 0,5037 & 0,2759 & Reliabel \\
\hline P8 & 0,4361 & 0,7510 & 0,2759 & Valid & 0,3783 & 0,4022 & 0,2759 & Reliabel \\
\hline $\mathrm{P9}$ & 0,6516 & 0,7313 & 0,2759 & Valid & 1,0204 & 0,4575 & 0,2759 & Reliabel \\
\hline $\mathrm{P} 10$ & 0,5895 & 0,8081 & 0,2759 & Valid & 0,5352 & 0,3952 & 0,2759 & Reliabel \\
\hline P11 & 0,6870 & 0,6825 & 0,2759 & Valid & 0,6813 & 0,4022 & 0,2759 & Reliabel \\
\hline $\mathrm{P} 12$ & 0,5572 & 0,7477 & 0,2759 & Valid & 0,5744 & 0,6651 & 0,2759 & Reliabel \\
\hline $\mathrm{P} 13$ & 0,7471 & 0,8091 & 0,2759 & Valid & 0,5613 & 0,6005 & 0,2759 & Reliabel \\
\hline P14 & 0,5765 & 0,6778 & 0,2759 & Valid & 0,2730 & 0,6398 & 0,2759 & Reliabel \\
\hline P15 & 0,6055 & 0,6984 & 0,2759 & Valid & 0,6997 & 0,3652 & 0,2759 & Reliabel \\
\hline P16 & 0,7385 & 0,8788 & 0,2759 & Valid & 0,6275 & 0,5198 & 0,2759 & Reliabel \\
\hline P17 & 0,4976 & 0,8321 & 0,2759 & Valid & 0,6997 & 0,4068 & 0,2759 & Reliabel \\
\hline P18 & 0,6738 & 0,8399 & 0,2759 & Valid & 0,5429 & 0,3237 & 0,2759 & Reliabel \\
\hline P19 & 0,7052 & 0,7320 & 0,2759 & Valid & 0,6159 & 0,3260 & 0,2759 & Reliabel \\
\hline P20 & 0,4976 & 0,7872 & 0,2759 & Valid & 0,6997 & 0,3676 & 0,2759 & Reliabel \\
\hline
\end{tabular}




\subsubsection{Customer satisfaction index (CSI) on jenggala commuter line}

The benefits of Customer Satisfaction Index (CSI) is to determine the level of user satisfaction of land transport services, especially trains [4]. Determining or measuring the level of user satisfaction of land transportation services can be determined by the CSI value indicator that considers the service user's expectation level of the factor to be defined.

Table 7. CSI Recommendations [5].

\begin{tabular}{|c|c|c|}
\hline \multicolumn{1}{|l|}{ No } & Number of Indeks & Interpretasi CSI \\
\hline 1 & $0,81-1,00$ & Very satisfied \\
\hline 2 & $0,66-0,80$ & Satisfied \\
\hline 3 & $0,51-0,65$ & Quite satisfied \\
\hline 4 & $0,36-0,50$ & Less satisfied \\
\hline 5 & $0,00-0,34$ & Not satisfied \\
\hline
\end{tabular}

Table 8. Results of Customer Satisfaction Index Calculation

\begin{tabular}{|c|c|c|c|c|}
\hline Attribute & $\begin{array}{c}\text { Expectation Level } \\
\text { Median Socre }\end{array}$ & $\begin{array}{c}\text { Importance } \\
\text { Weighting Factor } \\
(\boldsymbol{W F})\end{array}$ & $\begin{array}{c}\text { Level of } \\
\text { Statisfaction } \\
\text { Median Score }\end{array}$ & $\begin{array}{c}\text { Weighted } \\
\text { Score (WS) }\end{array}$ \\
\hline P1 & 4,45 & 0,051 & 4,22 & 0,21 \\
\hline P2 & 4,39 & 0,050 & 4,22 & 0,21 \\
\hline P3 & 4,20 & 0,048 & 4,10 & 0,20 \\
\hline P4 & 4,45 & 0,051 & 4,06 & 0,20 \\
\hline P5 & 4,35 & 0,049 & 4,24 & 0,21 \\
\hline P6 & 4,31 & 0,049 & 4,37 & 0,21 \\
\hline P7 & 4,25 & 0,048 & 4,16 & 0,20 \\
\hline P8 & 4,43 & 0,050 & 4,12 & 0,21 \\
\hline P9 & 4,33 & 0,049 & 4,14 & 0,20 \\
\hline P10 & 4,39 & 0,050 & 4,12 & 0,21 \\
\hline P11 & 4,39 & 0,050 & 4,16 & 0,21 \\
\hline P12 & 4,37 & 0,050 & 3,88 & 0,19 \\
\hline P13 & 4,45 & 0,051 & 4,22 & 0,21 \\
\hline P14 & 4,45 & 0,051 & 4,04 & 0,20 \\
\hline P15 & 4,45 & 0,051 & 4,08 & 0,21 \\
\hline P16 & 4,43 & 0,050 & 4,00 & 0,20 \\
\hline P17 & 4,51 & 0,051 & 4,08 & 0,21 \\
\hline P18 & 4,57 & 0,052 & 4,25 & 0,22 \\
\hline P19 & 4,45 & 0,051 & 4,18 & 0,21 \\
\hline P20 & 4,49 & 0,05 & 4,08 & 0,21 \\
\hline TOTAL & $\mathbf{8 8 , 1 4}$ & $\mathbf{1 , 0 0}$ & $\mathbf{8 2 , 6 9}$ & $\mathbf{4 , 1 3}$ \\
\hline & Customer satisfaction Index (CSI) & & $\mathbf{0 , 8 2 7}$ \\
\hline
\end{tabular}

With CSI value of 0.827 identified that users of Sidoarjo-Mojokerto commuter are at a very satisfied level (the values between of $0.81-1.00$ ). This is considered as quite good with the improvements made by PT. (Persero) Kereta Api Indonesia continuously to improve services toward consumers. 


\subsubsection{Important performance analysis (IPA)}

Importance-Performance Analysis (IPA) is a tool to analyze or to compare the extent to which performance / service can be perceived by service users compared to the expected level of satisfaction. The Importance Performance Analysis (IPA) method was first introduced by Marty and James with the aim to measure the relationship between consumer perceptions and the priority of product / service quality improvement, also known as quadrant analysis [4]. IPA has been generally accepted and used in various fields of study because of its ease application and display of analytical results that facilitate performance improvement proposals [6].

Table 9. Importance Performance Analysis (IPA) Jenggala Commuter Line.

\begin{tabular}{|c|c|c|c|c|c|}
\hline \multirow{2}{*}{ Attribute } & \multicolumn{2}{|c|}{ Satisfaction } & \multicolumn{2}{|c|}{ Expectations } & \multirow{2}{*}{$\begin{array}{l}\text { Comformity } \\
\text { Rate (\%) }\end{array}$} \\
\hline & $\mathbf{X i}$ & $(\mathbf{X})$ & $\mathbf{Y i}$ & $(\mathbf{Y})$ & \\
\hline The accuracy of the train travel schedule & 215 & 4,45 & 227 & 4,22 & 94,71 \\
\hline $\begin{array}{l}\text { Service schedule of current train } \\
\text { awareness }\end{array}$ & 215 & 4,39 & 224 & 4,22 & 95,98 \\
\hline $\begin{array}{l}\text { Officers always show attitude ready to } \\
\text { serve in helping the customer }\end{array}$ & 209 & 4,20 & 214 & 4,10 & 97,66 \\
\hline Safety and comfortability on board time & 207 & 4,45 & 227 & 4,06 & 91,19 \\
\hline $\begin{array}{l}\text { Available CCTV in train at least } 1 \text { piece } \\
\text { in } 1 \text { series }\end{array}$ & 216 & 4,35 & 222 & 4,24 & 97,30 \\
\hline $\begin{array}{l}\text { The evacuation point notice sticker is } \\
\text { easy to see and easy to read }\end{array}$ & 210 & 4,31 & 220 & 4,37 & 95,45 \\
\hline Seating number facility & 212 & 4,25 & 217 & 4,16 & 97,70 \\
\hline Toilet WC facilities & 210 & 4,43 & 226 & 4,12 & 92,92 \\
\hline Ticket price offered & 211 & 4,33 & 221 & 4,14 & 95,48 \\
\hline $\begin{array}{l}\text { The availability of fire extinguishers in } \\
\text { rail (APAR) }\end{array}$ & 210 & 4,39 & 224 & 4,12 & 93,75 \\
\hline Hygiene in trains & 212 & 4,39 & 226 & 4,16 & 93,81 \\
\hline $\begin{array}{l}\text { Availability of tools to inform the travel } \\
\text { route }\end{array}$ & 198 & 4,37 & 223 & 3,88 & 88,79 \\
\hline In-train seating facilities & 215 & 4,45 & 227 & 4,22 & 94,71 \\
\hline First Aid Kit & 206 & 4,45 & 227 & 4,04 & 90,75 \\
\hline Security officer / conductor & 208 & 4,45 & 227 & 4,08 & 91,63 \\
\hline $\begin{array}{l}\text { Path guidance and evacuation } \\
\text { procedures }\end{array}$ & 204 & 4,43 & 226 & 4,00 & 90,27 \\
\hline $\begin{array}{l}\text { There is an emergency telephone } \\
\text { number }\end{array}$ & 208 & 4,51 & 230 & 4,08 & 90,43 \\
\hline $\begin{array}{l}\text { Station information to be visited / } \\
\text { skipped sequentially }\end{array}$ & 217 & 4,57 & 233 & 4,25 & 93,13 \\
\hline $\begin{array}{l}\text { Information in a visual form placed in a } \\
\text { strategic place, as well as audio must be } \\
\text { sounds obvious }\end{array}$ & 213 & 4,45 & 227 & 4,18 & 93,83 \\
\hline Length of trip from nearest station & 208 & 4,49 & 229 & 4,08 & 90,83 \\
\hline \multirow[t]{2}{*}{ Total } & & 88,14 & & 82,69 & 1870,32 \\
\hline & $\overline{\bar{X}}=$ & 4,4 & $\overline{\bar{Y}}=$ & 4,1 & 93,5 \\
\hline
\end{tabular}




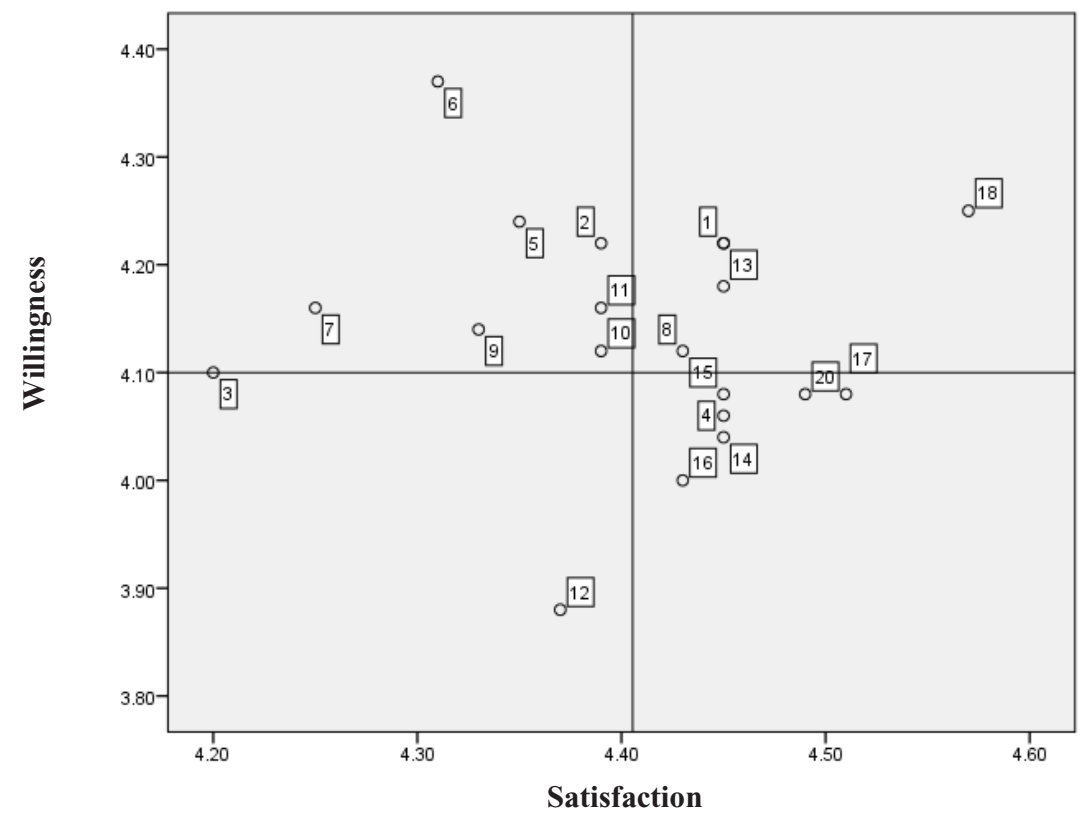

Fig. 3. Cartesian Diagram Importance Performance Analysis (IPA) Jenggala Commuter Line

From the IPA graphic results shows which attributes are included in the quadrant:

Quadrant I "Maintain Performance":

- The accuracy of the train travel schedule (attribute 1)

- Toilet WC facilities Functioning in accordance with the technical standards of operation and odorless clean coming from the toilet (attribute 8)

- In-train seating facilities (attribute 13)

- Station information to be visited / skipped sequentially (attribute 18)

- Information in a visual form placed in a strategic place, as well as audio must be sounds obvious (attribute 19)

Quadrant II "tends to be excessive":

- Safety and comfortability on board time (attribute 4)\

- First Aid Kit (attribute 14)

- Security officer / conductor (attribute 15)

- Path guidance and evacuation procedures (attribute 16)

- There is an emergency telephone number (attribute 17)

- Length of trip from nearest station (attribute 20)

Quadrant III "Low Priority":

- Availability of tools to inform the travel route (attribute 12)

Quadrant IV "Improve Performance":

- Service schedule of current train awareness (attribute 2)

- Officers always show attitude ready to serve in helping the customer (attribute 3)

- Available CCTV in train at least 1 piece in 1 series (attribute 5)

- The evacuation point notice sticker is easy to see and easy to read (attribute 6)

- Seating number facility (attribute 7)

- Ticket price offered (attribute 9)

- The availability of fire extinguishers in rail (APAR) (attribute 10)

- Hygiene in trains (attribute 11) 


\section{Conclusions}

In general, users of Jenggala commuter line are satisfied with the quality of service on the train.

- The condition of Jenggala commuter line has been complied the Minister of Transportation Regulation No. 48 of 2015 on Minimum Service Standards of Railway Transportation where all the criteria contained in the regulations are already exist and applied properly.

- Customer Satisfaction Index (CSI) determine the level of user satisfaction on land transportation services, especially railway. With a CSI value of 0.827 identified that the users of the Jenggala commuter line are at a very satisfied level (the values of 0.81 $1.00)$.

- Based on the respondents' answers obtained the level of conformity on Jenggala commuter line with an average IPA analysis of $93.5 \%$ which states the respondents are very satisfied with the services provided. The lowest level of conformity is found in attribute to (12) Availability of tools to inform the travel route $(88.79 \%)$, and highest in attribute to (7) seating number facility $(97.7 \%)$.

\section{References}

1. Department of Transportation of Indonesia, Regulation of the Minister of Communications No. 48 of 2015 on The National Transportation System. Jakarta (2012).

2. Hardiansyah. Quality of Public Service Concepts, Dimensions, Indicators, and Implementation. Yogyakarta (2011).

3. A, Parasuraman. The Behaviorial Consequence of Service Quality, Journal of Marketing, Vol 60. (2001).

4. Febriyanti, R. Analysis of Commuter Train Service Surabaya-Sidoarjo From The Side Of User Satisfaction. Surabaya: Institute of Technology Sepuluh Nopember (2009).

5. Tjiptono, F., and Chandra, Gregorious. Service, Quality, and Satisfaction. Ed 3, Yogyakarta: Andi Ofset (2011).

6. John A. Martilla and John C. James. Important Performance Analysis. (1997). 